\title{
PERILAKU PEMILIH (VOTERS BEHAVIOR) PEMILU PRESIDEN TAHUN 2014 DI KABUPATEN KEDIRI
}

\author{
Zainal Arifin dan Trinas Dwi Hariyana \\ Fakultas Hukum Universitas Islam Kadiri (UNISKA) \\ Jalan Sersan Suharmaji No.38 Kediri, Jawa Timur, Indonesia
}

\begin{abstract}
This study held in 2015, a year after the presidential election took place. Method used in the research methodwas to use a mixed method which is the qualitative descriptive method and quantitative methods. Based on the Method, having been obtained results of the research that the factors that make the basis for people who already have the right to vote in the Presidential and Vice Presidential Election 2014 in Kediri are a high rational consciousness to participate actively to be voters in the election of President and Vice President, and No linkages between levels of education and the economy voters with the voting behavior in the 2014 Presidential Election in Kediri. Information mediahad influences on voters' decisions in the election of President and Vice President in Kediri area 2014. The mass media played a role in improving the knowledge and to develop political awareness in the community at all levels, especially the marginalized in the medium group. There is no impact to the proximity of the candidates for President and Vice President of the behavior of voters in the district of Kediri in the 2014. Voters of presidential election in Kediri have got knowledge about politics. They chose the president based on the programs offered by candidates and neither to prioritize physical appearance / face candidates nor based on ethnicity / religion and region of origin.
\end{abstract}

Keywords : Voter Behavior, and the Presidential Election 


\begin{abstract}
ABSTRAK
Penelitian ini dlaksanakan pada tahun 2015 setahun setelah pemilu Presiden berlangsung. Metode yag di gunakan adalah Metode penelitian yang digunakan dalam penelitian ini adalah menggunakan metode campuran yaitu metode kualitatif deskriptif dan metode kuantitatif. Berdasarkan meote tersebut, didapatkan hasil penelitian bahwa Faktor yang menjadikan dasar bagi masyarakat yang sudah mempunyai hak pilih dalam Pemilu Presiden dan wakil Presiden 2014 di Kabupaten Kediri adalah kesadaran rasional yang tinggi untuk berpartisipasi aktif menjadi pemilih dalam Pemilu Presiden dan wakil Presiden .Tidak ada keterkaitan antara tingkat pendidikan dan tingkat ekonomi pemilih dengan perilaku pemilih dalam Pemilu Presiden 2014 di Kabupaten Kediri. Media informasi berpengaruh terhadap keputusan pemilih dalam Pemilu Presiden dan wakil Presiden di Kabupten Kediri tahun 2014. Media massa berperan dalam meningkatkan pengetahuan dan menumbuhkan kesadaran politik pada masyarakat di segala lapisan, terutama masyarakat yang terpinggir dalam kelompok menengah kebawah. Tidak ada pengaruh faktor kedekatan calon Presiden dan wakil Presiden dengan perilaku pemilih di Kabupaten Kediri dalam Pilpres 2014. Para pemilih di Kabupaten Kediri sudah mendapat pengetahuan politik. Mereka memilih presiden berdasarkan pada program yang ditawarkan capres, bukan mengutamakan penampilan fisik/wajah capres ataupun berdasarkan suku/agama dan daerah asal.
\end{abstract}

Kata Kunci: Perilaku Pemilih, dan Pemilu Presiden 


\section{A. PENDAhuluan}

\section{Latar Belakang Masalah}

Pemilihan Umum (Pemilu) merupakan salah satu perwujudan demokrasi. Pemilihan umum adalah proses memilih orang untuk mengisi jabatan-jabatan politik tertentu. Jabatan-jabatan tersebut beraneka-ragam, mulai dari presiden, wakil rakyat di berbagai tingkat pemerintahan, sampai kepala desa. ${ }^{16}$ Pemilihan Umum secara langsung mencerminkan kehidupan demokrasi rakyat dimana rakyat diberikan kebebasan untuk berpendapat atau berbicara dengan cara menggunakan hak pilihnya sebagai warga negara. Melalui pemilihan umum secara langsung, rakyat diajak ikut serta menentukan masa depan bangsa dengan ikut menentukan siapa yang layak menjadi pemimpin bangsa dan siapa yang layak menjadi wakil-wakil rakyat dalam menyalurkan aspirasi rakyat.

Sejak tahun 1955 Indonesia telah melakukan pemilihan umum secara langsung. Pemilihan umum saat itu hanya untuk memilih anggota DPR dan anggota konstituante. Sedangkan untuk pemilihan presiden secara langsung oleh rakyat pertama kali dilaksanakan pada tahun 2004. Tepatnya pada tanggal 20 September 2004, masyarakat Indonesia melakukan pemungutan suara untuk memilih presiden secara langsung. ${ }^{17}$ Sebelumnya, pemilihan presiden diadakan oleh Majelis Permusyawaratan Rakyat (MPR). Kemudian berdasarkan amanah yang tertuang dalam amandemen keempat UUD 1945 bahwa pemilihan presiden dan wakil presiden dilakukan secara langsung, umum, bebas, dan rahasia. Aturan tersebut semakin diperkuat dengan diberlakukannya Undang-Undang Nomor 23 Tahun 2003 tentang Pemilihan Umum Presiden dan Wakil Presiden yang kemudian diganti menjadi Undang-undang Nomor 42 Tahun 2008 tentang Pemilihan Umum Presiden dan Wakil Presiden. Undang-Undang Nomor 42 Tahun 2008 dalam pasal 2 menyatakan bahwa

\footnotetext{
${ }^{16}$ Pemilihan Umum, https://id.wikipedia.org/wiki/Pemilihan_umum, diakses Rabu 1 Juli 2015, jam 22.00 WIB.

${ }^{17}$ Sekilas pemilu dari masa ke masa, http://www.pusakaindonesia.org/sekilas-pemilu-darimasa-ke-masa/, diakses Rabu 1 Juli 2015, jam 22.00 WIB.
} 
Pemilu Presiden dan Wakil Presiden dilaksanakan secara efektif dan efisien berdasarkan asas langsung, umum, bebas, rahasia, jujur, dan adil.

Penyelenggaraan pemilu secara langsung bukan berarti tidak ada hambatan. Dugaaan kecurangan, bahkan blackcampaign selalu mewarnai pada saat menjelang pemilihan umum. Moneypolitics ataupun blackcampaign apapun bentuknya menjadi faktor yang dapat mempengaruhi hati nurani rakyat itu sendiri dalam menggunakan hak pilihnya, sedangkan pemilihan umum secara langsung memerlukan suara hati nurani rakyat yang benar-benar murni bahwa apa yang dipilihnya adalah murni pilihannya dan bukan karena adanya faktor $\mathrm{x}$, seperti blackcampaign ataupun moneypolitics.

Pemilihan Umum Presiden dan Wakil Presiden Republik Indonesia Tahun 2014 (disingkat Pilpres 2014) dilaksanakan pada tanggal 9 Juli 2014 untuk memilih Presiden dan Wakil Presiden Indonesia untuk masa bakti 2014-2019. Pemilihan ini menjadi pemilihan presiden langsung ketiga di Indonesia ${ }^{18}$. Pemilihan Presiden secara langsung pada tahun 2014 memberikan suasana berbeda dibanding Pemilihan Presiden pada tahuntahun sebelumnya. Kandidat presiden yang terdiri dari 2 (dua) pasang kandidat dengan latar belakang dan track record yang berbeda tetapi dengan pendukung-pendukungnya yang sama-sama kuat menjadikan persaingan antara kedua kandidat dalam pemilu tahun 2014 terasa lebih panas. Rakyat juga lebih antusias dalam mengikuti pemilihan umum presiden dan wakil presiden dibandingkan pemilihan presiden pada tahuntahun sebelumnya.

Terkait dengan hal itu, maka perlu ditelusuri faktor-faktor yang mendasari perilaku memilih dalam pemilu Presiden dan wakil Presiden.Tentunya banyak hal yang menjadi dasar pemilih dalam menjatuhkan pilihannya pada salah satu kandidat.

${ }^{18}$ https://id.wikipedia.org/wiki/Pemilihan_umum_Presiden_Indonesia_2014 diakses Rabu 1 Juli 2015, jam 22.00 WIB. 
Berdasarkan uraian tersebut maka melalui penelitian ini diharapkan dapat diketahui faktor-faktor apakah yang mempengaruhi perilaku pemilih dalam memilih kandidat pada saat Pemilihan Umum Presiden dan Wakil Presiden (Pilpres) tahun 2014 khususnya di Kabupaten Kediri.

\section{Rumusan Masalah}

a. Faktor apakah yang menjadi dasar pemilih dalam menggunakan hak pilihnya dalam pemilihan presiden dan wakil presiden 2014.

b. Apakah ada keterkaitan antara tingkat pendidikan dan tingkat ekonomi pemilih dengan perilaku memilih di Kabupaten Kediri.

c. Apakah media informasi berpengaruh terhadap keputusan pemilih.

d. Apakah faktor kedekatan berpengaruh pada keputusan pemilih.

\section{Tujuan Penelitian}

a. Untuk mengkaji secara mendalam faktor yang menjadi dasar pemilih dalam menggunakan hak pilihnya dalam pemilihan presiden dan wakil presiden 2014.

b. Untuk mengkaji secara mendalam keterkaitan antara tingkat pendidikan dan tingkat ekonomi pemilih dengan perilaku memilih di Kabupaten Kediri.

c. Untuk mengkaji secara mendalam media informasi berpengaruh terhadap keputusan pemilih.

d. Untuk mengkaji secara mendalam faktor kedekatan berpengaruh pada keputusan pemilih.

\section{B. METODE PENELITIAN}

\section{Metode Kuantitatif dan Kualitatif}

Indikator yang hendak diukur dalam penelitian ini adalah adanya pengaruh tingkat pendidikan dan tingkat ekonomi, kedekatan dan informasi terhadap pilihan Presiden di Kabupaten Kediri. Indikator tersebut didasarkan pada hipotesis sementara bahwa tingkat pendidikan dan tingkat ekonomi pemilih mempengaruhi perilaku pemilih. Untuk menemukan jawaban yang sebenarnya maka penelitian ini memerlukan 
suatu metode penelitian. Dalam suatu penelitian, metode merupakan suatu cara kerja yang diambil oleh peneliti dalam usahanya mencari, mengumpulkan, dan mengolah data, serta menuangkannya dalam bentuk laporan penelitian. Penelitian yang dilakukan dapat mencapai hasil yang sesuai dengan tujuan yang diharapkan serta dapat di pertanggung jawabkan kebenarannya secara menyeluruh jika memilih dan menggunakan metode penelitian yang sesuai. ${ }^{19}$

Metode penelitian yang digunakan dalam penelitian ini adalah menggunakan metode campuran yaitu metode kualitatif deskriptif dan metode kuantitatif. Pendekatan kualitatif memusatkan perhatian pada prinsip-prinsip umum yang mendasari perwujudan satuan-satuan gejala yang ada dalam kehidupan sosial. Sedangkan penelitian kualitatif adalah penelitian yang bermaksud untuk memahami fenomena tentang apa yang dialami oleh subyek penelitian, misalnya perilaku, motivasi, tindakan, dan lain-lain yang menghasilkan data deskriptif berupa kata-kata tertulis atau lisan dari orang-orang dan perilaku yang dapat diamati. Pendekatan kuantitatif ialah pendekatan yang didalam usulan penelitian, proses, hipotesis, turun ke lapangan, analisis data dan kesimpulan data sampai dengan penulisannya mempergunakan aspek pengukuran, perhitungan, rumus dan kepastian data numerik. ${ }^{20}$

Penelitian ini dilakukan di Kabupaten Kediri, Jawa Timur pada tanggai 25 Mei hingga 5 Juli 2015.Tim peneliti yang terlibat dalam penelitian ini 10 orang, terdiri dari ketua, wakil ketua, sekretaris, bendahara, dan peneliti utama, masing masing satu orang serta pembantu peneliti sejumlah lima orang. Dalam pengumpulan data, penelitian ini menggunakan sistem penyebaran angket ke populasi dengan sampel 10 persen dari total 1.182.255 pemilih yang tersebar di 26 kecamatan. Dengan sampel 10\% maka dari 26 kecamatan penelitian ini memilih lokasi sampel

\footnotetext{
${ }^{19}$ Suharsimi Arikunto, 1993, Prosedur Penelitian Suatu Pendekatan Praktek, Edisi Revisi. IV. Jakarta : Rineka Cipta, h. 215

20 Julia Brannen, Memadu Metode Penelitian Kualitatif dan Kuantitatif, 1997. PustakaPelajar, Yogyakarta, hal 90
} 
di 5 kecamatan di wilayah Kabupaten Kediri yaitu Kecamatan Kras, Kecamatan Ngasem, Kecamatan Semen, Kecamatan Purwoasri, dan Kecamatan Pare, dengan sampel informan total 153 pemilih yang menggunakan hak pilihnya dalam pemilihan presiden dan wakil presiden 2014.

Responden dalam penelitian ini terdiri dalam tujuh kelompok profesi, yakni Wiraswasta sejumlah 53 responden, TNI/Polri (2), PNS (7), Petani (19), Pedagang (14), Guru/Dosen (12), dan profesi lainnya (46).

Jumlah total responden sebanyak 153 orang. Teknik pemilihan responden dalam penelitian ini menggunakan teknik purposivesampling dan snowball, dimana pemilihan responden sudah ditentukan sebelumnya dan jumlahnya dapat bertambah.Dalam hal ini penentuan responden mencakup hampir seluruh unsur atau kalangan masyarakat yang menggunakan hak pilihnya pada Pemilu Presiden dan Wakil Presiden tahun 2014. Sehingga, diharapkan informasi atau data yang didapatkan lebih bervariasi. Selain menggunakan angket atau kuesioner, penelitian ini juga dilakukan dengan indepht interview (wawancara mendalam) secara terstruktur untuk memudahkan mendapatkan data secara maksimal berdasarkan masalah yang sedang diteliti dan ingin diketahui jawabannya oleh sumber informasi. Responden yang diinterview dalam hal ini adalah warga masyarakat di Kabupaten Kediri yang telah menggunakan hak pilihnya dalam pemilu 2014. Pengambilan data dalam penelitian ini akan menggunakan sumber data utama dalam penelitian kualitatif adalah katakata dan tindakan, selebihnya adalah data tambahan dan lain-lain.

Pengambilan data dilakukan dengan bantuan surveyor sebanyak 10 orang. Teknis pengumpulan data adalah metode kuesioner dan wawancara. Kedua metode dilakukan dalam dua tahap. Tahap pertama penyebaran kuesioner kepada 153 responden yang diasumsikan mewakili cluster atau kelompok profesi. Tahap kedua, wawancara mendalam dengan mengambil empat responden secara acak.Pada tahap wawancara mendalam, surveyor membacakan menyampaikan pertanyaan-pertanyaan yang substansi 
materinya merupaka bagian dari pertanyaan dalam kuesioner.Kemudian,responden menjawab dan surveyor merekam dan mencatat substansi jawaban responden ke dalam buku catatan.

Pada tahap penyebaran kuesioner, tidak jarang surveyor juga berperan sebagai asisten peneliti yang bertugas membantu menjelaskan pertanyaan dikuesioner kepada responden. Karena, dalam proses pengumpulan data survei, tidak jarang ada responden yang kurang atau tidak dapat menangkap maksud pertanyaan yang ada dikuesioner.

Sumber data utama dicatat melalui catatan tertulis atau melalui rekaman (audio tape recorder). Data yang dikumpulkan dari penelitian ini berasal dari hasil wawancara dengan responden, berbagai data yang didapat dari beberapa instansi, internet, dan juga tulisan-tulisan yang berhubungan dengan tema yang diteliti dan sangat membantu dalam penelitian ini.Penelitian ini merupakan jenis penelitian gabungan kuantitatif dan kualitatif. Sehingga, dalam pengolahan data akan dilakukan melalui tabulasi berikut analisis data kuantitatif serta deskripsi dan analisis hasil wawancara yang telah dilakukan dilapangan.

Bagan. 1 Skema Indikator dan Variabel Penelitian

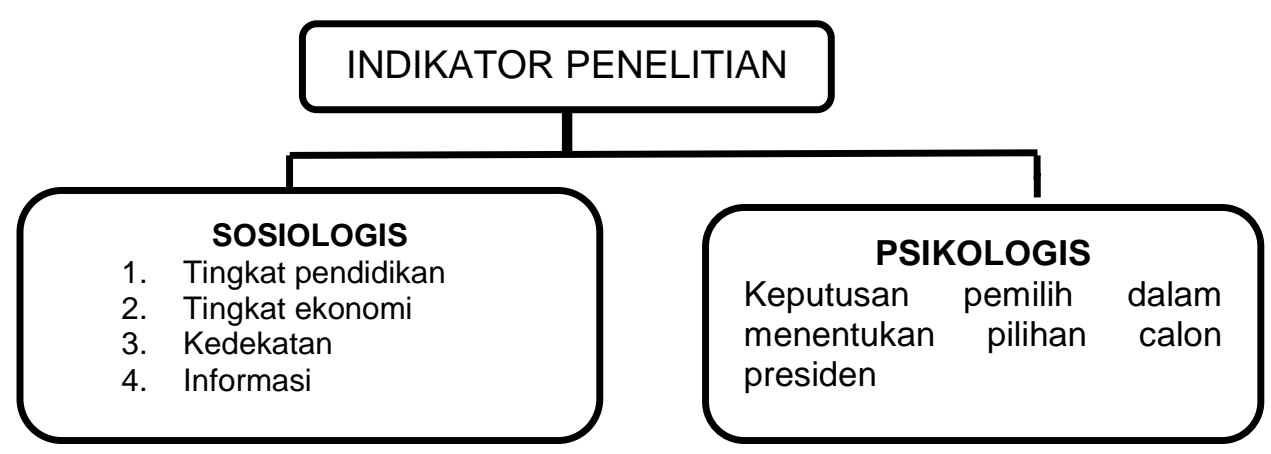




\section{Data dan Sumber}

\section{a. Data Primer}

Data primer diperoleh langsung dari objek penelitian, yakni melalui pengumpulan langsung dari objek penelitian.Caranya, memberikan kuesioner kepada responden dan wawancara mendalam dengan pengambilan sampel di antara responden.data primer terutama memuat database perihal responden atau karakteristik responden, antara lain jenis kelamin, usia, pekerjaan, dan penghasilan.

Dalam proses pencarian responden, penyebaran kuesioner, dan pengumpulannya kembali tentu saja ditemukan hambatan dan sejumlah kesulitan. Dari segi waktu pelaksanaan misalnya, penelitian dilaksanakan bersamaan bulan Ramadhan sehingga masyarakat tengah menjalankan ibadah puasa dan berdampak pada kecepatan penyebaran, pengisian, dan pengumpulankembali kuesioner. Selain itu, bersamaan pula dengan jam kerja dan masa pendidikan (kuliah) yang tidak optimal di masa bulan puasa serta kesibukan responden sehingga tidak dapat optimal dalam pengisian dan pengembalian kuesioner serta wawancara mendalam, meskipun pada akhirnya masih dapat dikejar untuk melakukan tabulasi dan analisis data.

b. Data Sekunder

Data sekunderdiperoleh dari buku Kediri dalam Angka (Badan Pusat Statistik Kabupaten Kediri) dan data Komisi Pemilihan Umum (KPU) Kabupaten Kediri.

c. Populasi dan Sampel

\section{1) Populasi}

Populasi adalah wilayah generalisasi yang terdiri atas obyek/subyek yang mempunyai kualitas dan karakteristik tertentu yang ditetapkan oleh peneliti untuk dipelajari dan kemudian ditarik kesimpulannya. $^{21}$ Atau seluruh individu atau objek yang akan diteliti, khususnya yang memiliki karakteristik tertentu yang

21 Syaifuddin Azwar, 2010, Metode Penelitian, Yogyakarta:, Pustaka Pelajar, hal.5 
ditetapkan oleh peneliti sebagai objek penelitian. Populasi diambil dari masyarakat Kabupaten Kediri yang telah dewasa, berusia 17 tahun atau sudah kawin/berkeluarga. Dari perkiraan populasi berusia dewasa, dapat dipetakan dari jumlah pemilih dalam Pemilu Legislatif dan Pemilu Presiden/Wakil Presiden pada 2009 dan khususnya jumlah pemilih pada Pemilu pada April 2014, yakni sebanyak 1.182.255 pemilih. Sementara untuk Pilpres tahun 2014, menurut Ketua KPU Kabupaten Kediri Sapta Andaruisworo,S.Pt, MMA pasangan nomor urut 1. H. Prabowo Subianto - Ir. H. M. Hatta Rajasa sebanyak 294.429 suara sedangkan pasangan nomor urut 2. Ir. H. Joko Widodo - Drs. H. M. Jusuf Kalla mendapat 619.456 suara. Suara sah sebanyak 913.885 suara dan suara tidak sah sebanyak 8.926 suara.

2) Sampel

Sampel merupakan bagian dari populasi yang diambil dari karakteristiknya yang dapat dianggap mewakili keseluruhan populasi. Sample penelitian adalah subjek yang mudah ditemui sehingga memudahkan pula proses pengumpulan data. ${ }^{22}$ Oleh karena itu, berdasarkan penetapan populasi tersebut, diambil responden sebanyak 153 orang dengan tingkat akurasi pengembalian kuesioner $100 \%$ atau kembali utuh sejumlah 153 eksemplar.

\section{Teknik Pengambilan Sampel}

Pengambilan sampel dilakukan dengan menerapkan metode pengambilan sampel cluster (baca: klaster) atau gugus. Subjek responden yang diambil ditetapkan berdasarkan seleksi kelompok sampel secara acak atau melakukan randomisasi terhadap kelompok, bukan terhadap subjek secara

22 Djarwanto, 1994, Pokok-pokok Metode Risetdan BimbinganTeknis Penulisan Skripsi, Yogyakarta, Liberty, dikutip dalam Research Center for Politics and Government (PolGov) Jurusan Politik dan Pemerintahan, FISIPOL UGM bekerjasama dengan The Asia Foundation (TAF)."Perilaku Pemilih dan Political Linkage di Kota Yogyakarta dan Kabupaten Magelang" Utilisasi Political Tracking sebagai Instrumen Pendidikan Pemilih dan Penguatan Engagement antara Politisi dan Konstituen. hal 2 
individual. ${ }^{23}$ Cara yang ditempuh, antara lain menyebarkan kuesioner di lingkungan institusi atau organisasi profesi, seperti pedagang, pengacara, akademisi (dosen dan mahasiswa), dan komunitas terbuka, seperti wiraswastawan ataupun pemilih pemula.

Sementara itu, untuk pelaksanaan metode kualitatif dilakukan dengan wawancara mendalam (in depth interview) yang melibatkan responden dari gugus akademisi, wiraswastawan, profesional, dan kelompok penyelenggara pemungutan suara, berusia antara 30-an tahun hingga 50-an tahun. Penelitian ini menggunakan dua pendekatan metode kuantitatif dan kualitatif agar dapat saling melengkapi dalam proses analisisnya. Selain itu, metode kualitatif dapat mengungkapkan hal-hal atau permasalahan yang bersifat terbuka yang tidak dapat diperoleh apabila penelitian hanya menggunakan metode kuantitatif. Metode kualitatif diterapkan dengan format wawancara mendalam kepada empat narasumber (responden).

\section{Teknik Pengumpulan Data}

Data diperoleh secara langsung dari responden yang menjadi objek penelitian.Data tersebut dikumpulkan melalui teknik pengumpulan kuesioner dan interview.

a. Kuesioner

Teknik pengumpulan data dengan cara mengajukan daftar pertanyaan tertutup yang disusun dalam berkas kuesioner kepada responden.

b. Interview

Teknik pengumpulan data dengan cara wawancara atau tanya jawab secara lisan dan langsung tatap muka dengan responden terkait dengan pokok masalah dalam penelitian. Pelaksanaan interview dilakukan dengan wawancara terbuka dan direkam serta dicatat.

\section{Teknik Analisis Data}

Data adalah suatu yang dapat dianalisis. Analisis data dilakukan dengan mengolah data dari hasil pendekatan dengan metode kuantitatif dan kualitatif. Analisis data dari metode kuantitatif dilakukan dengan

\footnotetext{
${ }^{23}$ Loc. Cit. Syaifudin Azwar hal 87
} 
pengelompokan berdasarkan karakteristik dasar responden, seperti jenis kelamin, pekerjaan, penghasilan, dan usia. Selain itu, dilakukan pembagian kelompok berdasarkan keterkaitan poin pertanyaan sebagai cara mempermudah analisis. $^{24}$

Demikian pula pada analisis data dari metode kualitatif juga menggunakan pengelompokan berdasarkan kesamaan dan kecenderungan dari mayoritas atau sebagian besar dari sampel yang diwawancara. ${ }^{25}$ Sehingga, dari dua metode kuantitatif dan kualitatif diperoleh kesimpulan yang tidak selisih jauh, bahkan diperoleh pola kecenderungan yang sama.

\section{PEMBAHASAN}

Hasil penelitian dilakukan dengan dua analisa. Yang pertama adalah analisa kuantitatif dan yang kedua adalah analisa kualitatif. Untuk analisa kuantitatif didapatkan beberpa temuan. Bagian ini merupakan hasil analisis dari data statistik Distribusi Frekuensi Variabel Penelitian. Dari 29 poin dirangkum ke dalam 10 poin sebagai berikut.

Karakteristik Responden bahwa penelitian ini diikuti oleh sebagian besar responden berpendidikan SMA atau sederajat dan berjenis kelamin lakilaki dengan profesi sebagai wiraswastawan serta berpenghasilan di bawah Rp 1 juta. Untuk Program Calon Presiden dan wakil Presiden Pilihan Responden sudah mengikuti Pilpres lebih dari 4 kali dan datang ke lokasi TPS dengan kesadaran sendiri dan memilih capres berdasarkan program yang disampaikan dalam kampanye, bukan karena pertimbangan suku/agama atau daerah (asal). Pilih Figur Calon Presiden dan wakil Presiden, Responden memilih capres lebih kepada sosok atau figur, bukan karena koalisi partai pengusung capres.Selain itu, responden memilih capres bukan karena suap atau pemberian uang.Jejak Rekam Capres, Responden memilih capres berdasarkan rekam jejak capres pilihan dan media massa memberikan informasi yang sangat membantu serta dijadikan rujukan dalam menentukan pilihan. Media

\footnotetext{
${ }^{24}$ Ida Bagus Matra.2004. Filsafat Penelitian dan Metode Penelitian Sosial. Yogyakarta: Pustaka Pelajar, hal 128

${ }^{25}$ Ibid.
} 
elektronik (televisi) sangat mempengaruhi responden dalam menentukan capres pilihan.Figur Capres: Pendidikan dan Wajah, Pendidikan capres yang menjadi pilihan responden tidak harus setingkat Sarjana.Wajah capres juga bukan menjadi pertimbangan responden dalam memilih capres.Tujuan dan Tahapan Pilpres, Responden mengetahui tujuan dan tahapan dilaksanakannya Pilpres., Syarat Pemilih Pilpres, Responden mengetahui siapa saja yang dibolehkan menjadi pemilih dalam Pilpres dan syarat-syarat untuk menjadi pemilih serta tata cara menggunakan hak pilih. Sumber Informasi Pemilu/Pilpres, responden mengetahui informasi perihal Pemilu/Pilpres dari media elektronik, (TV, Radio), media cetak (koran, majalah). Akan Memilih Lagi, responden menyatakan akan mengikuti Pilpres untuk 2019 mendatang. Hubungan Identitas, responden dalam memilih capres berdasarkan program dan kesamaan suku/agama atau daerah asal serta kesamaan partai politik.

Proses politik dalam menetapkan pilihan capres yang dilakukan responden tidak berkaitan dengan karakteristik personal responden, seperti jenis kelamin, pendidikan, pekerjaan, dan penghasilan. Pilihan responden juga tidak berdasarkan pada kesamaan suku/agama atau daerah asal serta koalisi partai politik pengusung capres.

Sementara untuk analisis kualitatif, adalah merupakan simpulan dari materi indephtinterview atau wawancara terbuka dengan empat responden. Keempat responden memiliki latar belakang profesi atau pekerjaan beragam, yaitu dosen merangkap petani berusia 33 tahun, pedagang dan pimpinan asosiasipedagang pasar (45 tahun), bankir yang menjadi panitia KPPS, dan pengacara (54 tahun).

Materi simpulan ini disusun berdasarkan kecenderungan kesamaan aspirasi atau pendapat dari mayoritas responden yang diwawancara. Bagian ini juga merupakan analisis dari pendekatan kualitatif. Pemilihan Umum/Presiden, Pmilihan Presiden (Pilpres) yang dilaksanakan secara langsung merupakan bagian dari pembangunan politik yang demokratis.Warga negara Indonesia seharusnya menggunakan hak pilih karena Pilpres menjadi momentum untuk perubahan menjadi lebih baik.Program Capres Pilihan, 
masyarakat cenderung memilih capres berdasarkan program yang disampaikan pasangan capres/cawapres pada saat kampanye.Dari pilihan program, masyarakat berharap terjadi perbaikan dan kesejahteraan bagi masyarakat.Politik Uang, masyarakat cenderung menolak pemberian uang untuk motif kepentingan politik bagi capres/cawapres tertentu.Pemberian uang dianggap tidak menghargai harga diri warga Negara dan tidak dapat mempengaruhi suara mereka. Capres dan Afiliasi Politik Partai, masyarakat cenderung memilih Capres pilihan bukan karena partai politik dan koalisinya yang mengajukan pasangan capres/cawapres, melainkan karena figur atau sosok capres yang bersangkutan. Rekam Jejak Capres, masyarakat memerlukan informasi yang objektif tentang rekam jejak capres. Informasi Rekam Jejak Capres, masyarakat memerlukan media massa yang menginformasikan perihal rekam jejak capres secara objektif. Tujuan Pilpres, masyarakat memahami tujuan Pilpres untuk memilih pemimpin yang diharapkan dapat mengelola pemerintahan menjadi lebih baik dan membawa perubahan bagi kehidupan bernegara dan bermasyarakat menjadi lebih baik.Tahapan Pemilu/Pilpres, masyarakat memahami tahapan Pilpres. Syarat Pemilih Presiden, masyarakat memahami syarat untuk menjadi pemilih atau peserta Pilpres. Syarat Capres (Calon Presiden), masyarakat memahami syarat menjadi capres. Tata Cara Pemilihan Presiden, Masyarakat memahami tata cara pemilihan presiden. Asal Informasi Soal Calon Dipilih, masyarakat mengetahui informasi mengenai capres dari media massa. Akan Memilih Lagi, masyarakat menyadari untuk menggunakan hak pilih dalam Pilpres dan akan memilih lagi jika diselenggarakan Pilpres.

\section{PENUTUP}

\section{Kesimpulan}

Berdasarkan hasil analisis data melalui metode kuantitatif dan kualitatif, diperoleh kecenderungan adanya kesamaan atas perilaku pemilih pada Pemilu Presiden/Wakil 2014 di Kabupaten Kediri. 
a. Faktor yang menjadikan dasar bagi masyarakat yang sudah mempunyai hak pilih dalam Pemilu Presiden dan wakil Presiden 2014 di Kabupaten Kediri adalah kesadaran rasional yang tinggi untuk berpartisipasi aktif menjadi pemilih dalam Pemilu Presiden dan wakil Presiden .

b. Tidak ada keterkaitan antara tingkat pendidikan dan tingkat ekonomi pemilih dengan perilaku pemilih dalam Pemilu Presiden 2014 di Kabupaten Kediri.

c. Media informasi berpengaruh terhadap keputusan pemilih dalam Pemilu Presiden dan wakil Presiden di Kabupten Kediri tahun 2014. Media massa berperan dalam meningkatkan pengetahuan dan menumbuhkan kesadaran politik pada masyarakat di segala lapisan, terutama masyarakat yang terpinggir dalam kelompok menengah kebawah.

d. Tidak ada pengaruh faktor kedekatan calon Presiden dan wakil Presiden dengan perilaku pemilih di Kabupaten Kediri dalam Pilpres 2014. Para pemilih di Kabupaten Kediri sudah mendapat pengetahuan politik. Mereka memilih presiden berdasarkan pada program yang ditawarkan capres, bukan mengutamakan penampilan fisik/wajah capres ataupun berdasarkan suku/agama dan daerah asal. 


\section{DAFTAR PUSTAKA}

Djarwanto, Pokok-pokok Metode Risetdan BimbinganTeknis Penulisan Skripsi,Yogyakarta, Liberty, dikutip dalam Research Center for Politics and Government (PolGov) Jurusan Politik dan Pemerintahan, FISIPOL UGM bekerjasama dengan The Asia Foundation (TAF)."Perilaku Pemilih dan Political Linkage di Kota Yogyakarta dan Kabupaten Magelang" Utilisasi Political Tracking sebagai Instrumen Pendidikan Pemilih dan Penguatan Engagement antara Politisi dan Konstituen, 1994 Ida Bagus Matra, Filsafat Penelitian dan Metode Penelitian Sosial. Yogyakarta: Pustaka Pelajar,2004.

Julia Brannen, Memadu Metode Penelitian Kualitatif dan Kuantitatif,. PustakaPelajar, Yogyakarta, 1997

.Suharsimi Arikunto, Prosedur Penelitian Suatu Pendekatan Praktek, Edisi Revisi. IV. Jakarta : Rineka Cipta, 1993

Syaifuddin Azwar, Metode Penelitian, Yogyakarta:, Pustaka Pelajar, 2010.

Website: https://id.wikipedia.org/wiki/Pemilihan_umum, Pemilihan Umum, diakses Rabu: 1 Juli 2015

http://www.pusakaindonesia.org/sekilas-pemilu-dari-masa-ke-masa/, Sekilas Pemilu dari Masa ke Masa, diakses: Rabu 1 Juli 2015 https://id.wikipedia.org/wiki/Pemilihan_umum_Presiden_Indonesia_2014, diakses: Rabu 1 Juli 2015 